\title{
関連項目数が隠匿情報検査時の心理的・ 生理的反応に及ぼす影響
}

科学警察研究所

小川 時洋

科学警察研究所

松田いづみ

科学警察研究所

常岡 充子

\section{Effects of Single- and Multiple-relevant Items Conditions on Differential Psychological and Physiological Responses on the Concealed Information Test}

\author{
Tokihiro OGAwA \\ First Information Science Section, National Research Institute of Police Science \\ Izumi MATSUDA \\ First Information Science Section, National Research Institute of Police Science \\ Michiko TsuneOKA \\ First Information Science Section, National Research Institute of Police Science
}

Characteristic physiological responses on the concealed information test (CIT) have been a topic of interest. The present study compared physiological responses and self-reported emotion between a single relevant item and a multiple relevant items condition. Participants performed a mock theft where they were asked to steal one or three accessories. They were also asked to choose one or three cards, each indicating a color name. If participants stole one accessory, they would choose three cards; if participants stole three accessories, they would choose one card. Then, participants underwent the CIT, which assessed stolen items and selected colors. The relevant-irrelevant differences in physiological measures, such as skin conductance, respiratory speed, heart rate, and normalized pulse volume, were smaller in the three-relevant items condition than in the one-relevant item condition. Self-reported measures indicated that participants felt surprise and tension during the relevant item presentation. However, the number of relevant items in the question set did not affect self-reported emotion. These results indicate dissociation between physiological and self-reported measures on the CIT.

Key words: concealed information test, physiological response, emotion, stimulus probability

2014.10.23受稿，2015.6.2受理，2015.7.23 J-STAGE早期公開， doi: 10.5674/jjppp. 1415oa, JOI: JST.JSTAGE/jjppp/1415oa 連絡者及び連絡先：テ277-0882 千葉県柏市柏の葉 6-3-1 科学警察研究所情報科学第一研究室 小川時洋

E-mail: t-ogawa@nrips.go.jp 
【要 約】隠匿情報検查 (CIT) 時の生理反応の特徵は, この分野の研究トピックスであり続けている。本研究で は, 関連項目の数が1個の場合と複数ある場合とで, 生理反応および自己報告された感情を比較した。実験参加 者は，模擬穷盗でアクセサリーを1個ないし3 個盗むことを求められた。また，色の名前を示すカードを 3 枚な いし1枚, ブラインドで選択するよう求められた。次に実験参加者は, 盗んだアクセサリーもしくは選んだ色の 名前を尋ねるCITを受けた。生理測度における関連-非関連項目の差異は, 関連項目が3個の場合には, 関連項目 が1個の場合に比べて小さくなった。自己報告測度は, 実験参加者が関連項目提示時に驚きや緊張を感じていた ことを示した。しかしながら, 質問中の関連項目の数は, 自己報告尺度の感情には影響しなかった。これらの結 果は, CIT時の生理反応と自己報告測度に乘離があることを示唆する。

隠匿情報検査（concealed information test: CIT）ま たは有罪知識検査 (guilty knowledge test: GKT, Lykken, 1959）は，現在の我が国の犯罪捜査で，事件に関わっ た者のみが知り得る犯罪事実の記憶の有無を調べるた めに実施されるポリグラフ検査のパラダイムである (小林ら, 2009；小川ら，2013)。CITでは, 事件事 実と一致する内容を持つと考えられる項目と, それと 類似するが事件事実ではないと考えられる内容を持つ 複数の項目を組み合わせた質問表を用意し, 質問項目 を提示しながら検査対象者の生理活動を記録する。質 問項目を一通り提示することをもって1セットとし， 提示順序を変えて複数セッ卜実施する。検查対象者が 特定の項目を事件関連項目としてとらえている場合, その項目に対して他の項目とは異なる弁別的な生理反 応が見られる。一方, 検査対象者が何れの質問項目も 事件関連項目と見なしていない場合, 反応は質問項目 間で似通ったものとなる。この質問時の生理反応の背 後にある心理的・生理的プロセスや, 各種要因が生理 反応に及ぼす影響の解明は, CIT の実施上の留意点等 を明らかにする上で重要卜ピックスである (Verschuere \& Ben-Shakhar, 2011)。

本研究では, CIT時の生理反応に影響を及ぼすこと が知られている質問表中の関連項目の数の効果につい てさらに検討を行う。これまで複数の研究が, 関連項 目の提示比率が, 関連・非関連項目間の皮膚コンダク タンス反応 (skin conductance response: SCR) の差異 に影響を及ぼすことを報告している（Ben-Shakhar， 1977; Ben-Shakhar et al., 1975; Lieblich et al., 1970)。一般にCITの質問表は, 関連項目 1つと複数 の非関連項目で構成される。関連項目が複数含まれる など高頻度で提示される場合には, SCRの差異が小 さくなる (Ben-Shakhar, 1977)。この点について, Ben-Shakhar et al.（1975）は，慣れとその般化が，関
連・非関連項目で独立から同様に生じるため, 刺激の 提示比率が等しい場合には, 項目間の差異が小さくな ると論じている。この考えは, 二分化理論 (dichotomization theory) として知られている。

一方, SCR以外の生理指標に対する刺激提示比率 の影響は不明であり, 検討が必要である。現在のCIT では, 研究でも実務でもSCRに加えて呼吸運動, 心 拍率 (heart rate: HR), 規準化脈波容積 (normalized pulse volume: NPV, 廣田ら，2003）などを計測して いる。このうち, 例えば脈波容積は慣れが生じにくい ため (廣田ら, 2003), 関連項目数の操作の影響を受 けないかもしれない。また, SCRは, 幾つかの実験 的操作に対して他の指標とは異なる応答を示す。例え ば，関連項目に対して正直に“はい”と返答するか, “いいえ”と虚偽の返答をするかの違い (Ambach et al., 2008）や，刺激の自己関連性（花山ら，2011）の 操作がSCRに及ぼす影響は, HRに比べて小さいこと が示唆されている。したがって, 刺激提示比率の影響 が指標によって異なるかどうかは, CITで用いる生理 反応の特徴を把握する上で重要である。

また, 本研究では刺激提示比率を, 質問表中に含ま れる関連項目の数を変えることで操作した。提示比率 の操作としては，1個の関連項目をセット内で複数回 提示する (Lieblich et al., 1970), 質問表の全項目数 を変える（Ben-Shakhar et al., 1975）等, 幾つかの方 法が考えられる。しかし，実践の場ではセット内で同 じ項目を繰り返すことはない。一方，様々な情報に基 づいて慎重に質問項目を選んだとしても, 結果として 関連項目が質問表中に複数含まれることはあり得る。 もし, 関連項目が複数含まれる場合に, これらの生理 指標でも関連・非関連項目の差異が小さくなるのであ れば，そのような質問表では記憶を有するにも関わら ず，“記憶なし”と判断するフォールス・ネガティブ 
(False negative) の危険が高まる可能性がある。質問 表中に関連項目の数が複数ある場合の生理反応の傾向 の把握は，応用的にも意義がある。

さらに本研究では, 関連項目提示時・非関連項目提 示時に生起した感情にも焦点を当てた。CITの背景メ カニズムに関する研究は, 便宜的に感情・動機づけア プローチと, 定位反応を中心概念とした認知的アプ ローチに大別される (Verschuere \& Ben-Shakhar, 2011)。しかし, 両者は対立するものではない。例え ば, Lykken（1974）は，CIT時の反応を定位反応と位 置づけている。定位反応生起時には，驚き体験が伴う (Niepel, 2001）という報告がある。また概念的にも， 定位反応の誘発因となる有意性は, 動機づけや感情要 因をも包摂する (Dindo \& Fowles, 2008)。

また, 従来のCIT研究では, 質問紙等で感情を測定 した事例は少なく, 質問提示時にどんな感情が喚起さ れるのかや, 生理反応との関連は不明である。本研究 では, 質問紙を用いて関連項目提示時と非関連項目提 示時の感情を測定して比較する。また，二分化理論か らは, 関連項目の提示比率が高い場合, 少なくとも SCRでは項目間の差異が小さくなると予測される。 一方, 感情は主観的体験, 生理反応, 行動が緩やかに 絡み合った複合的現象であり, 要素間の関連・相関は 必ずしも強い関連が見られないことも多い (Cacioppo et al., 1996; Lazarus, 1991; Mauss et al., 2005)。した がって, もし質問紙得点において項目間の差異が見ら れたとしても, 関連項目の提示比率が質問紙得点にど のような影響を及ぼすかは不明である。本研究では, 関連項目の提示比率の操作を通じて，CITに打ける質 問紙得点と生理反応の関係についても探索的に検討す る。

本研究では, 質問表中に関連項目が1個だけ含まれ る条件と, 半数含まれる条件を設定し, 各条件での生 理反応および質問提示時の感情を質問紙で測定した。 実験では，6項目2質問表のCITを実施した。一方の 質問表は, 関連項目が 1 個, 非関連項目 5 個であり, もう一方の質問表は, 関連項目・非関連項目が各 3 個 で構成された。生理指標として, SCR, 呼吸運動, HR, NPVを計測した。関連項目提示時・非関連項目 提示時に生起した感情は, 一般感情尺度 (小川ら, 2000）の肯定的感情（positive affect: PA）, 否定的感 情 (negative affect: NA), 安静 (calm: CA) および多
面的感情状態尺度（寺崎ら，1992）の驚愕尺度と集中 尺度を用いて測定した。

\section{方 法}

実験参加者 実験協力に同意した成人 34 名（男 17 名, 女17名）が実験に参加した。年齡は21-41歳 (平均 $31.56 \pm 4.81$ 歳) であった。実験参加者には, 謝 礼として交通費を含めた 7000 円相当のインターネッ トショップポイントが支払われた。

装置 実験は, シールドルーム内で行った。生理反 応の測定には，デジタルポリグラフ装置（PTH-347, ティアック）を用い, SCR, 呼吸運動, HR, NPVを 記録・測定した。各生理指標は, $1 \mathrm{kHz}$ のサンプリン グレートでデジタル変換して記録した。SCR測定の ための皮膚伝導度測定は，ディスポ電極（PPS-EDA， ティアック）を実験参加者の非利き手の第 $2 \cdot 3$ 指末 節に装着し， $0.5 \mathrm{~V}$ の定電圧回路を用いて導出した信 号を, $5 \mathrm{~Hz}$ のハイカット・フィルターを通した後, 時定数 $5 \mathrm{~s}$ で増幅して行った。呼吸運動は, 実験参加 者のみぞおち付近に呼吸ピックアップ (PP-C011, ティアック）を装着し，得られた信号を直流増幅, $5 \mathrm{~Hz}$ のハイット・フィルターを通して記録した。 HR 計測のために, 両足首と右手首にディスポ電極を 装着し, 時定数 $0.1 \mathrm{~s}, 30 \mathrm{~Hz}$ のハイカット・フィル ターを通して心電図を導出・記録した。各拍動のHR を，心電図の R-R 間隔時間に基づいてオンラインで算 出した。NPV測定のため, 透過型指尖容積脈波のプ ローブを非利き手第4指に装着した。NPVは，時定 数 $0.3 \mathrm{~s}$ で増幅した波形から求めた各拍動の脈波振幅 を, 対応する同一心周期の直流值の平均で除したもの を，オンラインで1拍ごとに算出することで求めた。

質問紙 一般感情尺度（小川ら，2000）のPA， NA， $\mathrm{CA}$ の 3 尺度の各 8 項目と, 多面的感情状態尺度（寺崎 ら，1992）の驚愕尺度と集中尺度から各4 項目を選ん で用いた。一般感情尺度の項目は, PA尺度には“陽 気な”“楽しい”，NA尺度には“恐ろしい”“緊張した”， CA尺度には“くつろいだ”“静かな”などが含まれて いた。多面的感情状態尺度の驚愕尺度は, “はっとし た”“びくりとした”，集中尺度は“鋭敏な”“注意深い” などであった。各項目について, “全くあてはまらな い”を 1 ，“非常にあてはまる”を4とする4件法で評定 
を求めた。

手続き 実験は個別に実施した。実験参加者は, 最 初に実験での役割を決定するためのくじを引いた。続 いて，シールドルーム内に入室し，くじに“犯人”と 記されていた場合は, 実験者の退室後に“ネクタイピ ン”“イヤリング”“ネックレス”“ブローチ”“指輪”“時 計”の何れかのアクセサリーが一つずつ入った封筒 を, 部屋にある引き出しから窃取し, 中身を確認した 上で隠し持っておくように教示した。実験参加者の半 数には, 封筒を 1 通だけ盗み, 残り半数には封筒を 3 通盗むよう教示した。一方，くじに“無実”と書かれ ていた場合には, 何もせずに部屋で待機するよう教示 した。実際のくじは, 全て “犯人”であった。模擬窃 盗の終了後, 実験参加者を肘掛け椅子に着席させて電 極を装着した。続いて, 実験参加者は, “茶色” “黄 色” “白色” “赤色” “黑色” “青色”の色名を記したカー ドが入った封筒を選んだ。模擬突盗で封筒を 1 通だけ 窃取するよう教示した参加者には色名カード入りの封 筒を 3 通, 模擬突盗で 3 通窃取するよう教示した参加 者にはカード入り封筒を 1 通だけ選ばせ, 中のカード に記された色名を記憶させた。

続くCITでは, 実験参加者が選んだカードに記され た色を尋ねるカード検查の質問表と, 模擬穷盗で盗ん だアクセサリーを尋ねる質問表の計2質問表を実施し た。盗んだアクセサリーおよび覚えたカードの色名は 関連項目, それ以外は非関連項目になる。カード検査 と模擬突盗の検查の実施順序は, 実験参加者間でカウ ンターバランスをとった。教示では, 検査は盗んだア クセサリーや，選んだカードに記された色が何であっ たかを尋ねるものであること, 実験参加者の課題は, 全ての質問に対して否定の返答を行って, 窃取品や カードの色が何かを隠すことであることを教示した。 さらに，動機づけを高めることを意図して，検出され るかどうかは, 知能, 意志, 感情のコントロールと関 係することを説明し，隠している情報が見破られない ように努力するよう教示した。質問項目数は, 模擬窃 盗検査，カード検查とも6項目であった。これらの6 項目の提示を 1 セットとし, 提示順序を変えて各々 6 セット実施した。質問提示には, 実験参加者の前方に 設置したスピーカーとディスプレイを用いた。スピー カーからは予め録音した音声ファイルを $25 \mathrm{~s}$ 間隔で提 示し，音声のオンセットにあわせて質問項目を漢字扮
よびカタカナの文字表記で $5 \mathrm{~s}$ 間ディスプレイ上に提 示した。質問に対しては, すべて口頭で “いいえ”と 返答するように求めた。各質問表の終了後に, 記憶確 認のため, 実際に窃取したアクセサリー, 選んだカー ドの色の報告を求めた。続いて, 模擬窃盗検査・カー ド検査それぞれの関連項目提示時と非関連項目提示時 に感じた感情を質問紙で回答するよう求めた。実験終 了後, 動機づけを高めるための教示を行ったことを謝 意と共に説明した。

データ分析 質問紙は, 各尺度の項目の平均值を分 析した。SCRは, 質問提示後から $5 \mathrm{~s}$ 以内に生起した 変化の最大振幅として計測した。呼吸運動は返答から $15 \mathrm{~s}$ 間を, $20 \mathrm{~Hz}$ にリサンプリングして $4 \mathrm{~Hz}$ の高域遮 断フィルタをかけた。続いて, この区間の呼吸波形に おける振幅方向の絶対的変化量の合計值を解析時間 (15 s) で除した呼吸速度を求めた。HR, NPVは, 質 問提示後 $5 \mathrm{~s}$ から $15 \mathrm{~s}$ までの平均值を求めた。これら の各測度について, 実験参加者毎に72個（2質問表 $\times$

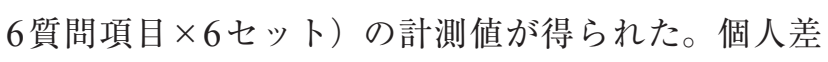
の影響を除去するため, これらの值を個人内で標準化 $\iota^{1)}$, 質問別に関連・非関連項目毎に平均値を求め た。

\section{結 果}

生理指標の計測不良が多かった男女各 1 名のデー夕 を, 分析から除外した。また, 全ての実験参加者が, 関連項目を正しく報告した。

生理反応 $\mathrm{SCR}$ の分析からは, $0.03 \mu \mathrm{S}$ 以上の SCR が半数に満たなかった 5 名を除外した。計測エラーの ため, 呼吸運動の分析では3名, HR・NPVの分析で は各1名を除外した。Table 1には, 各生理指標の条 件別 - 項目別の平均, 標準誤差, Cohen's $d$ による項 目間の差異の効果量を揭出した。関連項目提示時に は, 非関連項目提示時に比べて, より大きな SCR, 低い呼吸速度とHR, NPVが見られた。

関連項目の数 $\times$ 項目の分散分析の結果, 項目の主効 果は，全ての指標で有意であった（SCR: $F(1,26)=$ $29.28, p<.001, \eta^{2}=.089$; 呼吸速度 $: F(1,28)=11.71$, $p=.002, \eta^{2}=.062$; HR: $F(1,30)=28.23, p<.001, \eta^{2}$ $\left.=.131 ; \mathrm{NPV}: F(1,30)=8.86, p=.006, \eta^{2}=.019\right)$ 。関 連項目の数の主効果は, 有意ではなかった $(p \mathrm{~s}$ 
Table 1. Averages and effect sizes of physiological measures.

\begin{tabular}{|c|c|c|c|c|c|c|}
\hline \multirow{2}{*}{ Measures } & \multirow{2}{*}{$\begin{array}{c}\text { Number of } \\
\text { Relevant item }\end{array}$} & \multicolumn{2}{|c|}{ Relevant } & \multicolumn{2}{|c|}{ Irrelevant } & \multirow{2}{*}{$d$} \\
\hline & & $M$ & $S E$ & $M$ & $S E$ & \\
\hline SCR & 1 & 0.38 & 0.13 & -0.03 & 0.07 & 0.78 \\
\hline$(N=27)$ & 3 & 0.06 & 0.07 & -0.13 & 0.08 & 0.48 \\
\hline $\mathrm{RS}$ & 1 & -0.28 & 0.12 & 0.05 & 0.07 & 0.66 \\
\hline$(N=29)$ & 3 & -0.07 & 0.07 & 0.09 & 0.09 & 0.37 \\
\hline HR & 1 & -0.27 & 0.10 & 0.21 & 0.08 & 0.97 \\
\hline$(N=31)$ & 3 & -0.26 & 0.09 & 0.00 & 0.07 & 0.59 \\
\hline NPV & 1 & -0.15 & 0.09 & 0.05 & 0.08 & 0.44 \\
\hline$(N=31)$ & 3 & -0.04 & 0.07 & 0.01 & 0.08 & 0.12 \\
\hline
\end{tabular}

Note. Abbreviations mean as follows. SCR: skin conductance response, RS: respiratory speed, HR: heart rate, NPV: normalized pulse volume.

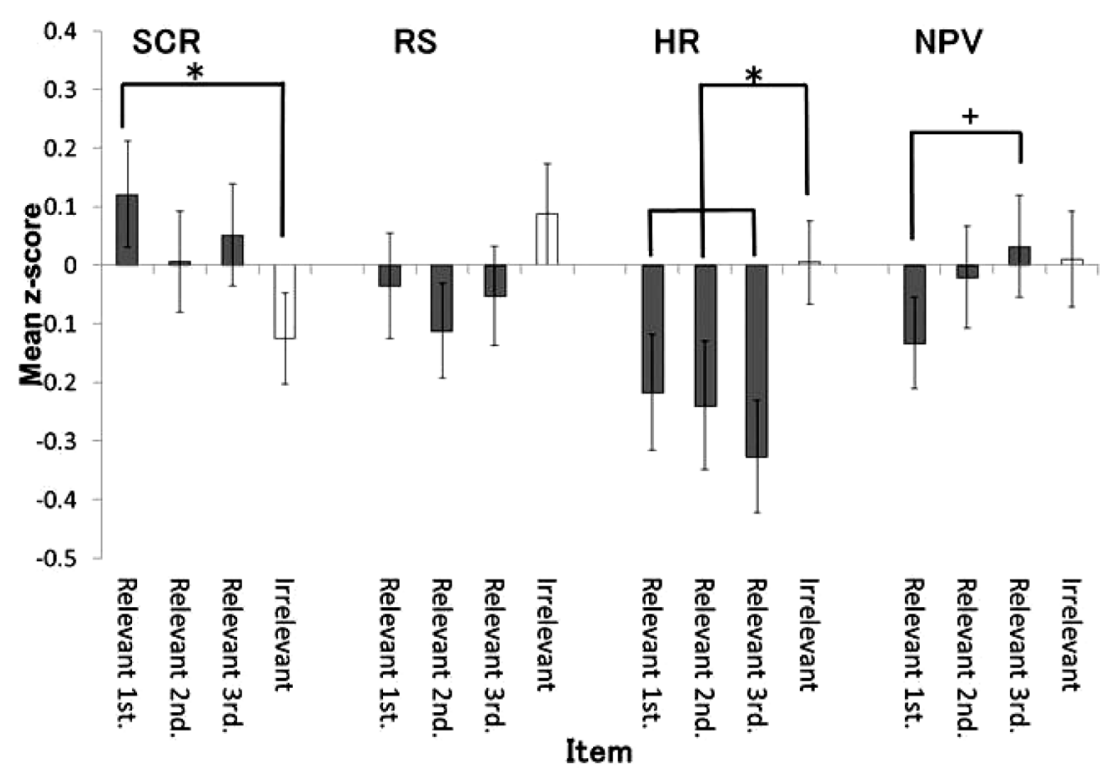

Figure 1. Standardized means for physiological measures in the three-relevant items condition.

Note. SCR: skin conductance response, RS: respiratory speed, HR: heart rate, NPV: normalized pulse volume. Bars indicate standard errors. ${ }^{*} p<.05,+p<.10$.

$>.203)$ 。関連項目の数 $\times$ 項目の交互作用は $\mathrm{SCR}$ と HRで有意 $\left(\mathrm{SCR}: F(1,26)=4.45, p=.045, \eta^{2}=.013\right.$; HR: $\left.F(1,30)=4.98, p=.033, \eta^{2}=.010\right)$, 呼吸速度抒 よびNPVで有意な傾向を示した (呼吸速度 : $F(1,28)$ $=2.96, p=.096, \eta^{2}=.008 ; \mathrm{NPV}: F(1,30)=3.88$, $\left.p=.058, \eta^{2}=.007\right)$ 。

各生理測度における関連項目と非関連項目の差異 は, 質問表に含まれる関連項目が1個の場合により顕 著であった。下位検定の結果，質問表に含まれる関連 項目が 1 個の場合には, 関連・非関連項目間の差異は 全ての測度で有意であった $(p s<.001)$ 。関連項目が3
個含まれる条件でも，1個の場合と同様の項目間の差 異が見られたが，その差異の効果量が1個の場合に比 べて小さい傾向が一貫して見られた。関連項目が 3 個 含まれる条件の $\operatorname{SCR}(p=.023)$ と HR $(p=.002)$ で は, 項目間の差異は有意であったが, 呼吸速度では有 意傾向 $(p=.084), \mathrm{NPV}$ では有意ではなかった $(p$ $=.371)$ 。

関連項目が 3 個の条件で, 関連・非関連項目の反応 の差異が小さくなった原因として, 関連項目に対する 反応のセット内変動が考えられる。例えば, 関連項目 に対するSCRは, セット内で次第に小さくなり, 結 
Table 2. Averages and effect sizes of self-reported emotion $(N=32)$.

\begin{tabular}{|c|c|c|c|c|c|c|}
\hline \multirow{2}{*}{ Measure } & \multirow{2}{*}{$\begin{array}{c}\text { Number of } \\
\text { Relevant item }\end{array}$} & \multicolumn{2}{|c|}{ Relevant } & \multicolumn{2}{|c|}{ Irrelevant } & \multirow{2}{*}{$d$} \\
\hline & & $M$ & $S E$ & $M$ & $S E$ & \\
\hline \multirow[t]{2}{*}{ Positive Affect } & 1 & 1.32 & 0.09 & 1.53 & 0.12 & 0.37 \\
\hline & 3 & 1.32 & 0.08 & 1.57 & 0.12 & 0.43 \\
\hline \multirow[t]{2}{*}{ Negative Affect } & 1 & 2.32 & 0.14 & 1.56 & 0.11 & 1.09 \\
\hline & 3 & 2.07 & 0.15 & 1.40 & 0.08 & 0.97 \\
\hline \multirow[t]{2}{*}{ Calm } & 1 & 1.68 & 0.15 & 2.16 & 0.17 & 0.53 \\
\hline & 3 & 1.63 & 0.13 & 2.23 & 0.17 & 0.71 \\
\hline \multirow[t]{2}{*}{ Surprise } & 1 & 2.38 & 0.16 & 1.48 & 0.10 & 1.22 \\
\hline & 3 & 2.19 & 0.14 & 1.36 & 0.10 & 1.24 \\
\hline \multirow[t]{2}{*}{ Concentration } & 1 & 2.20 & 0.15 & 1.77 & 0.13 & 0.55 \\
\hline & 3 & 2.11 & 0.15 & 1.61 & 0.10 & 0.69 \\
\hline
\end{tabular}

Note. PA: positive affect, NA: negative affect, CA: calmness.

果として全体的な関連・非関連項目の差異が小さく なったのかもしれない。この可能性を検討するため, 関連項目が3個含まれる条件の各生理指標について, 非関連項目の平均と, 1 番目・2番目・3番目の関連項 目 (Figure 1) を, 1要因4水準の分散分析によって比 較した。自由度の調整には Greenhouse-Geisserの $\varepsilon を$ 用いた。主効果は, $\operatorname{SCR}(F(3,78)=3.09, \varepsilon=.896$, $\left.p=.038, \eta^{2}=.041\right) \quad$ お よ びHR $(F(3,90)=6.54, \varepsilon$ $\left.=.856, p=.001, \eta^{2}=.179\right)$ では有意, NPVでは有意 傾向 $(F(3,90)=2.56, \varepsilon=.859, p=.070)$ であった。 TukeyのHSD検定から, SCRでは最初の関連項目の みが有意に非関連項目より高く $(d=0.57), \mathrm{HR}$ では全 ての関連項目が非関連項目に比べて有意に低かった $(d \mathrm{~s}=0.47-0.71)$ 。NPVでは最初の関連項目が，3番 目の関連項目よりも低い傾向が見られた $(d=0.37)$ 。 呼吸速度では主効果は有意ではなかった $(p=.150)$ 。

質問紙 Table 2 に各条件の平均, 標準誤差, Cohen's $d$ による項目間の差異の効果量を尺度別に掲 出した。NA・驚愕・集中の各尺度の得点は, 関連項 目提示時の方が非関連項目提示時に比べて高く, PA とCA尺度では逆の傾向が見られた。項目間の差異の 効果量は, $\mathrm{NA}$ 驚愕尺度で大きく, 集中と CA, PA の順に続いた。

項目の主効果は全ての尺度で有意であった（PA: $F(1,30)=9.54, p=.004, \eta^{2}=.038$; NA: $F(1,30)=$ 27.02, $p<.001, \eta^{2}=.206$; CA: $F(1,30)=18.18$, $p<.001, \eta^{2}=.087$; 驚愕: $F(1,30)=41.81, p<.001$, $\eta^{2}=.272$; 集 $\quad$ 中: $F(1,30)=17.31, p<.001, \eta^{2}$

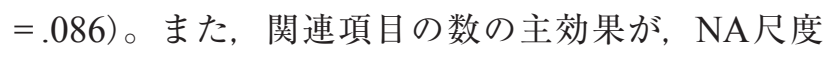
で有意 $\left(F(1,30)=4.35, p=.045, \eta^{2}=.017\right)$, 驚愕尺 度で有意な傾向を示し $\left(F(1,30)=3.20, p=.083, \eta^{2}\right.$ $=.009)$, 関連項目が 1 個の場合の方が, 3 個の場合よ りも全体的に得点が高かった。交互作用は有意ではな かった $(p \mathrm{~s}>.311)$ 。

\section{考 察}

実験の結果, CITの質問表に含まれる関連項目の数 は, 関連・非関連項目間の生理反応の弁別的反応に影 響を及ぼした。質問表中に含まれる関連項目が1個の 場合, 先行研究 (小林ら, 2009; 小川ら, 2013) と同 様, 関連項目提示時は, より大きな SCR, 小さな呼 吸運動, 低いHRとNPVが見られた。しかし, 関連 項目が3個含まれる条件では, 1個の場合に比べて関 連・非関連項目の差異の効果量が全ての指標で小さく なった。これらの結果は, 複数の関連項目を含む質問 表では, フォールス・ネガティブがより起こりやすく なることを示す2)。先行研究 (Ben-Shakhar, 1977) と 同様, 関連項目の比率が高い場合に関連 - 非関連項目 間のSCRの差異が小さかった。さらに，セット内の 最初の関連項目に対するSCRが, 他の関連項目より も数值的に大きかった点は, 二分化理論と符号するよ うに見える。

しかし, 全体として本研究の結果を二分化理論から 
説明することは困難である。例えば，SCRにおける 関連項目間の差異は有意ではなく, 二分化理論が想定 する関連項目に対するSCRの慣れは, 本研究におい て見られたとは言い難い。さらに, 呼吸速度とHRの 何れにおいても関連項目間の差異は有意ではなかっ た。これらの結果は, 有意刺激 (Lykken, 1974) もし くは信号価を持つ刺激 (Ben-Shakhar et al., 1975) で は, 慣れが生じにくい（Lynn, 1966）と言われている ことと一致する。また, 本研究が用いた分析手続きに も注意する必要がある。本研究を含む日本のCIT研究 の多くは, HRやNPVを刺激提示前の水準からの一過 性の変化ではなく, 絶対值として分析している（花山 ら, 2011; 廣田ら, 2003 ; 小林ら, 2009; 小川ら, 2013)。一般に慣れは, 刺激反復に伴う一過性の反応 の減少として概念化されている。したがって本研究の 結果を, 慣れに依拠する二分化理論で説明することは 困難であるが，これは二分化理論を否定するものでは ない。

なお，刺激の提示比率と生理反応の関係について は, なお検討すべき点も残る。例えば, 関連項目が1 個でも, 質問表の全項目数が4個（関連項目の提示確 率は $25 \%)$ の場合と，5個 (20\%), 7個（14\%）等の場 合で, 各生理反応の差異がどの程度異なるかの検討 は, 応用的な意義があるであろう。また, 実際の検查 手続きと解離するが, 同じ提示確率でも, 関連項目が 5 項目中に 1 個の場合と, 10 項目中に 2 個の場合では, 項目間の差異が同じかどうかを検討することも考えら れる。

一方, 本研究は, CITの関連項目が非関連項目に比 べて高い緊張や驚愕を誘発することをはじめて示し た。関連項目提示時の感情を尋ねた場合の感情尺度得 点は, 非関連項目提示時に比べて, 驚愕・NA・集中 尺度では得点が高く, PAやCA得点は低かった。平 均値が3点を越えた尺度はなく, 強い感情が生じたと はいえないが, 驚愕やNA尺度等, 関連・非関連項目 間の差異には, Cohen's $d か ゙ 1.00$ 以上となったものも 見られた。CIT時の生理反応が定位反応であるという 見方 (Lykken, 1974) を踏まえると, これらの結果 は, 定位反応生起時に驚き体験が伴うという報告 (Niepel, 2001) とも整合する。

また, 関連・非関連項目間の感情の違いは, CITの 手続きに内在する要因がもたらしたと考えられる。本
研究で質問項目に用いた色やアクセサリー自体は, ヌード写真や人体切断写真など, 他の感情誘発実験で 用いられる刺激に比べると, 強い感情価を持つ刺激と は考えにくい。さらに, 関連項目となる質問項目は, 実験参加者ごとに異なったため, 項目間の感情の違い を特定の質問項目の特徵・性質に帰すことはできな い。また, カード検査や模擬窃盗手続きも, 強い感情 や, 検出されることで被る不利益への強い恐怖が生じ る状況とは見なしにくい。本研究の結果は, CIT とい う課題・状況自体に, 本来中性的な刺激を感情喚起刺 激に変える性質があることを示唆する。このような感 情喚起的性質の生成メカニズムや性質の検討は, 感情 研究としても興味深いテーマとなるだろう。

一方, 生理反応とは異なり, 関連項目の数の違い は，感情尺度得点には影響を及ぼさなかった。その意 味で, 本研究では, 言語報告と生理反応が一対一に対 応しなかった。感情尺度の得点は, 個々の質問に対す る生理反応と直接関連するのではなく, 関連項目の有 意性や信号価と関連するのかもしれない。別の可能性 として, 生理指標に比べ質問紙得点は, 関連項目の数 の操作に対する応答性が低い指標とも考えられる。だ が, 感情現象において自己報告と生理反応には, しば しば弱い関連しか見られない (Cacioppo et al., 1996; Mauss et al., 2005）ことを踏まえると, 感情尺度と生 理反応の関連については, 言語報告の測定方法の工夫 を含めて, 今後さらに検討の必要がある。その他に も, 感情と CIT時の生理反応の関連については, 感情 尺度得点に対する, 質問刺激自体の感情価（小林ら, 2005）や，記銘時の感情状態 (Osugi \& Ohira, 2006), 虚偽の返答か真実の返答かの影響 (Ambach et al., 2008), 自己関連性 (花山ら, 2011), 抑制 (Verschuere et al., 2007) や隠蔽 (Matsuda et al., 2013）の影響などが検討課題として挙げられる。

本研究は, 質問表中の関連項目の数が多ければ, SCR以外の生理指標においても, 質問に対する弁別 的反応が小さくなることを示した。また，CITの関 連・非関連項目提示に対しては, 異なる感情が報告さ れることを明らかにした。この感情という観点・切り 口からのCIT研究は, CIT研究に新たな拡がりをもた らすと考えられる。CITの質問時に感情が生じたとい う本研究の結果は, 記憶の有無を調べるというCITの 使用目的とは矛盾しない。関連項目が, 非関連項目と 
は異なる感情を誘発したとしても, その感情は, 検査 対象者が事件事実を知っているからこそ生じるもので ある。CIT時の感情尺度得点の違いをもたらす要因 や, 感情との関わりからのメカニズムの検討は, 記憶 の検查という実際場面でのCITの使用目的とは独立 に,一つのアプローチとして成立しうる。

\section{注}

1）質問表ごとの標準化は, 関連項目の数が異なる場 合には不適切である。例えば, どちらの条件でも 全ての関連項目に $5 \mu \mathrm{S}$, 全ての非関連項目に $0 \mu \mathrm{S}$ のSCRが生じたとする。しかし, 質問表ご とに標準化すると, 関連項目に対する標準化 SCRは, 関連項目が 1 個では $2.24,3$ 個では 1 とな り，異なった数值となる。

2）いくつかの生理指標では, 関連項目が 3 個含まれ る条件でも項目間の差異が有意であったことにも 留意すべきである。フォールス・ネガティブが増 えることは，検出が不可能であることを必ずしも 意味しない。

\section{引用文献}

Ambach, W., Stark, R., Peper, M., \& Vaitl, D. (2008). Separating deceptive and orienting components in a concealed information test. International Journal of Psychophysiology, 70, 95-104.

Ben-Shakhar, G. (1977). A further study of the dichotomization theory in detection of information. Psychophysiology, 14, 408-413.

Ben-Shakhar, G., Lieblich, I., \& Kugelmass, S. (1975). Detection of information and GSR habituation: An attempt to derive detection efficiency from two habituation curves. Psychophysiology, 12, 283-288.

Cacioppo, J. T., Berntson, G. G., \& Crites, S. L. (1996). Social neuroscience: Principles of psychophysiological arousal and response. In E. T. Higgins \& A. W. Kruglanski (Eds.), Social psychology: Handbook of basic principles. New York, NY: Guilford Press. pp. 72-101.

Dindo, L., \& Fowles, D. C. (2008). The skin conductance orienting response to semantic stimuli: Sig- nificance can be independent of arousal. Psychophysiology, 45, 111-118.

花山愛子 · 山元修一 ·渋谷友祐 (2011). 非裁決項目 の自己関係性が隠匿情報検査における生理反応に 及ぼす影響 心理学研究, 82, 459-466.

(Hanayama, A., Yamamoto, S., \& Shibuya, Y. (2011). Effect of self-relevance of a non-critical item on physiological responding on the Concealed Information Test. Japanese Journal of Psychology, 82, 459-466.)

廣田昭久 - 澤田幸展 - 田中豪一 - 長野祐一郎・松田い づみ・高澤則美（2003）。新たな精神生理学的虚 偽検出の指標：規準化脈波容積の適用可能性 生 理心理学と精神生理学, 21, 217-230.

(Hirota, A., Sawada, S., Tanaka, G., Nagano, Y., Matsuda,I., \& Takasawa, N. (2005). A new index for psychophyisological detection of deception: Applicability of normalized pulse volume. Japanese Journal of Physiological Psychology and Psychophysiology, 21, 217-230.)

小林孝寛・吉本かおり・鈴木直人 (2005)。記憶情報 の感情価が虚偽検出検查時の生理反応に及ぼす影 響 感情心理学研究, 12, 82 .

(Kobayashi, T., Yoshimono, K., \& Suzuki, N.) 小林孝寛・吉本かおり・藤原修治 (2009). 実務ポリ グラフ検査の現状 生理心理学と精神生理学, 27, 5-15.

(Kobayashi, T., Yoshimoto, K., \& Fujihara, S. (2009). The contemporary situation of field polygraph tests. Japanese Journal of Physiological Psychology and Psychophysiology, 27, 5-15.)

Lazarus, R. S. (1991). Emotion and adaptation. New York, NY: Oxford University Press.

Lieblich, I., Kugelmass, S., \& Ben-Shakhar, G. (1970). Efficiency of GSR detection of information as a function of stimulus set size. Psychophysiology, 6, 601-608.

Lykken, D. T. (1959). The GSR in the detection of guilt. Journal of Applied Psychology, 43, 385388.

Lykken, D. T. (1974). Psychology and the lie detector industry. American Psychologist, 29, 725-739. 
Lynn, R. (1966). Attention, arousal and the orienting readction. NY: Pergamon Press.

Matsuda, I., Nittono, H., \& Ogawa, T. (2013). Identifying concealment-related responses in the concealed information test. Psychophysiology, 50, 617-626.

Mauss, I. B., Levenson, R. W., McCarter, L., Wilhelm, F. H., \& Gross, J. J. (2005). The tie that binds? Coherence among emotion experience, behavior, and physiology. Emotion, 5, 175-190.

Niepel, M. (2001). Independent manipulation of stimulus change and unexpectedness dissociates indices of the orienting response. Psychophysiology, 38, 84-91.

小川時洋・松田いづみ・常岡充子 (2013). 隠匿情報 検査の妥当性一一記憶検出技法としての正確性の 実験的検証一 日本法科学技術学会誌, 18, 35-44.

(Ogawa, T., Matsuda, I., \& Tsuneoka, M. (2013). Accuracy of concealed information test as a memory detection technique: A laboratory Study. Japanese Journal of Forensic Scinece and Technology, 18, 35-44.)

小川時洋・門地里絵・菊谷麻美・鈴木直人 (2000). 一般感情尺度の作成心理学研究, 71, 241-246.
(Ogawa, T., Monchi, R., Kikuya, M., \& Suzuki, N. (2000). Development of the general affect scales. Japanese Journal of Psychology, 71, 241246.)

Osugi, A., \& Ohira, H. (2006). Effects of emotional arousal on the concealed information test (CIT) : A study by event related potential and autonomic indices. Psychophysiology, 43, S74.

寺崎正治・岸本陽一 - 古賀愛人 (1992). 多面的感情 状態尺度の作成心理学研究, 62, 350-356.

(Terasaki, M., Kishimoto, Y., \& Koga, A. (1992). Construction of a multiple mood scale. Japanese Journal of Psychology, 62, 350-356.)

Verschuere, B., \& Ben-Shakhar, G. (2011). Theory of the Concealed Information Test. In B. Verschuere, G. Ben-Shakhar, \& E. Meijer (Eds.), Memory detection: Theory and application of the concealed information test. New York, NY: Cambridge University Press. pp. 128-148.

Verschuere, B., Crombez, G., Koster, E. H., Van Bockstaele, B., \& De Clercq, A. (2007). Startling secrets: startle eye blink modulation by concealed crime information. Biological Psychology, 76, $52-60$. 